Dicle University Journal of Engineering (DUJE)

web: http://dergipark.gov.tr/dumf

Derleme Makalesi / Review Article

\title{
Otonom Araçların Özellikleri, Mevcut Durumu ve Gelecekteki Yerinin Ulaştırma ve Trafik Üzerine Etkisi Bağlamında İncelenmesi
}

\section{A Review of Characteristics and Existing Case and Future Position of Autonomous Vehicles on the Context of Effects over Transportation and Traffic}

\author{
Mehmet Çağnı Kızıltaş ${ }^{1 *}$ \\ ${ }^{l}$ İstanbul Ticaret Üniversitesi, İnşaat Mühendisliği Bölümü, İstanbul, mckiziltas@ticaret.edu.tr
}

\begin{tabular}{l} 
MAKALE BİLGİLERİ \\
\hline Makale geçmişi: \\
Geliş: 5 Aralık 2019 \\
Düzeltme: 8 Eylül 2020 \\
Kabul: 9 Eylül 2020 \\
\hline Anahtar kelimeler: \\
Otonom araçlar, otonom sürüş, \\
penetrasyon, karma trafik, \\
teknolojik ilerleme
\end{tabular}

\section{ÖZET}

Otonom araçlar geleceğin ulaștırma ve kentleşmesini șekillendirecektir. Ve gelecekteki ulaștırmada temel taşlardan birisi olacaktır. Bu bağlamda mevcut ulaştırma ve trafik sistemine penetrasyonu on yıllar alacak olup söz konusu ulaştırma türü ile mevcut otomobillerden (konvansiyonel araç) oluşan bir karma trafikten bahsedilecektir. Buna göre trafik akımı, trafik akım hızı, trafik güvenliği, trafik düzen ve sürekliliği, șerit disiplini, takip mesafesi, konfor gibi hususlar penetrasyon düzeylerine göre sürekli bir değişim gösterecektir. Bunun bir düzen ve istikrarı yakalaması uzun yıllar alacak bir süreçtir. Otonom araçların trafik düzeni, trafik akım hızı, verimi, otopark yer tasarrufu, trafik güvenliği ve seyahat kilometreleri gibi konuları geliştirmesi beklenen bir durumdur. Ancak söz konusu heterojen akım dâhilindeki orta vadede bütün bu özelliklerin, karma trafiğin getirileri ve uygulama tecrübeleri bağlamında büyük değişiklikler göstermesi beklenebilmektedir. Bunun iyi yönetimi için şimdiden safhalarına göre iyi kavranması, analizi ve yorumu gerekecektir. Bu çalışmada öncelikle otonom araçların temel özellikleri ele alınmaktadır. Ardından mevcut durumu değerlendirilmekte ve otonom arac seviyelerinden bahsedilmektedir. Bu çerçevede de kullanıcı nezdinde kabulü irdelenmekte ve bu bağlamda sonuç ve öneriler paylașılmaktadır.

Doi: 10.24012/dumf.655830

\begin{tabular}{l} 
ARTICLE INFO \\
\hline Article history: \\
Received: 5 December 2019 \\
Revised: 8 September 2020 \\
Accepted: 9 September 2020 \\
\hline Keywords: \\
Highway, Autonomus vehicle, \\
penetration rates, traffic flow, \\
traffic safety, comfort
\end{tabular}

traffic safety, comfort

\begin{abstract}
Autonomous vehicles will form the future's urbanization and transportation. And they will be a cornerstone in the future's transportation system. On this context penetration of autonomous vehicles to existing transportation and traffic system is going to take tens of years that aforementioned transportation mode and conventional vehicles (automobiles) are going to constitute a heterogeneous traffic. In terms of these, traffic flow, traffic flow velocity, traffic order and continuity, traffic safety, lane discipline, following distance, comfort and related elements are going to show a continuous change according to various penetration rates. Taking a stability of these trend can get a trend which equals to tens of years. It is excepted that traffic order of autonomous vehicles are going to improve various elements as traffic efficiency, parking place savings, traffic flow velocity, traffic safety and travel kilometers. But within aforementioned heterogeneous traffic flow, in medium term all of these features can be expected to show big changings on the context of mixture traffic characteristics and implementation experiences. For good management of this process, at that moment it is a necessity to god understand, analyze and interpretation of these on a multi-phase approach. In this paper firstly the main features of autonomous vehicles are discussed. After these, existing case of autonomous vehicles is evaluated and levels of autonomy and autonomous vehicles are entreated. Within this scope the satisfactory by user of autonomous vehicles is examined and conclusions and recommendations are shared.
\end{abstract}




\section{Giriş}

Otonom araçlar (OA) muhtelif faydalar temin etmek ve de muhtelif maliyetler empoze etmektedir. Otonom araçlar (OA) sürücü stres ve bıkkınlığını azaltabilir. Kendinden sürüşlü araçlar yolcuların seyahat esnasında daha üretken olmasına ya da dinlenmesine imkân tanımak sureti ile hareketli (mobil) oyun odaları, ofisler ya da yatak odaları halini alabilmektedir. Bu da seyahat süresi birim maliyetlerini azaltması muhtemel bir durumu teşkil etmektedir.

Diğer bir taraftan ise de kendinden sürüşlü araçlar yeni stres ve konforsuzluklar da üretebilmektedir. $\mathrm{Bu}$ çerçevede temizlik ve Vandalizm maliyetlerini en aza indirmek için kendinden sürüşlü taksiler ve otobüsler güvenlik kameraları, küçük aksesuarlar ve sıkı bir içyapıya sahip olmaktadir (sentetik koltuklar ve paslanmaz çelik yüzey). Talep karşılığı sürüş ise emniyeti (güvenlik) azaltacaktır ve seyahat süresi ve güvenilirliğini de azaltacaktır. Bunun nedeni ise özellikle de çıkmaz sokaklı dağınık kentsel bölgelerde her bir ilave biniş ve iniş, diğer yolculara birkaç dakikalık bir gecikme olarak yansiyacaktır [1].

Otonom araçlar (OA) muhtelif donanım ve hizmetleri gerektirmektedir. Bunlar; sensörler, otomat kontrol, yazılım, hizmet birimleri (server), güç kaynakları, telsiz ağlar, kısa mesafeli araçtan araca iletişim, uzun mesafeli haritaya erişim, yazılım yükseltmeleri, karayolu raporları, seyrüsefer (navigasyon), küresel konumlanma sistemleri (KKS_GPS), özel yüksek kalite haritalar ve kritik unsur test ve bakımıdır.

Trafik Güvenliği ve Emniyeti:

- Donanım ve yazılım bozulmaları

- Kötü niyetli hekleme

- Artan risk alma

- Dizi riskleri

- Artan ortalama araç seyahatleri

- Otomobil dişı yolculara ilave riskler

- Geleneksel güvenlik stratejilerine yatırımların azaltılması
Avukatlar iddia etmektedir ki otonom sürüş trafik tıkanıklığı, enerji tüketimi, kirlilik salımları, karayolu ve otopark tesis maliyetleri dâhil olmak üzere harici maliyetleri azaltacak olmasına karşı söz konusu bu faydalar ise belirsiz olmaktadır. Daha etkin olması adına otonom araçlar (OA) dizi için münhasır şeritleri gerektirmektedir. $\mathrm{Bu}$ sadece kademeli olarak bölünmüş otoyollarda uygulanabilirdir.

Önceki araç teknolojisi tertibi ile edinilen deneyim:

- Otomatik iletim

- Hava yastıkları

- Hibrid araçlar

- Abonman araç hizmetleri

- Araç seyrüsefer sistemleri

Otonom araç (OA) tasarımı ve programlanmasinda kullanıcı ve toplumsal hedefler arasında potansiyel çelişkiler bulunmaktadır. Örneğin eğer ki uyuyan yolcuların konforunun maksimize edilmesi (azami hale getirilmesi) programlanıyor ise trafik hızlarını düşürebilir ve de eğer ki işgalcileri korumak için programlanıyor ise de diğer karayolu kullanıcilarına olan kaza riskini artmaktadır. Çeşitli faydaların teşekkül etmesi ise de otonom araçlara (OA) münhasır şerit gerektirmektedir. Bu söz konusu gereksinimlerin şeffaflık, fiyat, tanzim ve tahkimi hakkında tartışmalar ortaya çıkmaktadır [1].

Otonom araçların (OA) faydaları, maliyetleri, seyahat etkileri, hız ve tüketici talepleri hususunda ise dikkate değer ölçülerde belirsizlikler bulunmaktadır. Otonom araç (OA) faydaları ile ilgili abartılı ve söylentiden ibaret olan birçok tahmin söz konusu olmaktadır. En iyimser tahminler ise kişisel bilgisayarlar, akıllı telefonlar ve dijital kameralar gibi diğer yenilikçi teknolojiler dâhilindeki deneyimlere dayalı olaraktan endüstride finansal ilgiye sahip insanlar tarafindan gerçekleştirilmektedir.

2020'ler ve 2030'lar boyunca birçok kentsel alanda kendinden sürüşlü taksiler ve mikro toplu ulaştırma hizmetleri elverişli hale gelmiş 
olacaktır. İnsan sürüşlü taksilerden daha ucuz olup kendinden sürüşlü taksiler tahmini olaraktan 0,60-1 ABD doları/mil maliyetinde olacak olup mikro transitte (küçük toplu ulaştırma) ise bu söz konusu durumun 30-60 sent/mil olarak ortaya çıkması öngörülmektedir. Fakat daha düşük hizmet kalitesi önermektedir, öyle ki temizlik ve bakım maliyetleri minimize edilmekte olup dâhili donanım ise metal ve plastikten oluşmaktadır, araçta yolcular ise kamera ile izlenecektir, yeni binen yolcular öncekilerin çöp, koku ya da lekeleri ile karşılaşabilecektir [2].

Otonom araçlar (OA) kendi mücavir alanını algılayabilme ve de insan müdahalesi olmaksızın hareket edebilme yeterliliğinde olan araçlardır. $\mathrm{Bu}$ araçlar aynı zamanda sürücüsüz, kendinden sürücülü, insansız ya da robotik araçlar olaraktan da bilinmektedirler. 2016 y1lında ise Uluslararas1 Otomotiv Mühendisleri Topluluğu (SAE OMT) ilk olarak 2014 yılında ortaya koymuş oldukları otonom araçlar (OA) ile ilgili terminolojilerini değiştirmiştir ve otonom araçların (OA) düzeylerini otomasyon kademelerine göre belirlemișlerdir. $\mathrm{Bu}$ konuda Otomotiv Mühendisleri Topluluğunun (SAE_OMT) düşüncesi ise de söz konusu düzeylerin şekilsel olmaktan çok tanımlayıcı, yasalarla ilgili olmaktan çok teknik olduğuna temellenmektedir. Bunların pazar penetrasyonları ile ilgili olarak ise herhangi bir çıkarım ya da ifadede bulunulmamıştır.

Otonom araçlar (OA) birçok veçhe dikkate alınaraktan değerlendirilmelidir. Bunlar:

- Teknik

- Yasal

- Trafik güvenliği

- Çevresel

- Pazar penetrasyonu

- Ahlaki (etik)

Veçhelerden (aşama) mütevellittir.

Yeni teknolojiler yakıt tüketimini azaltmak sureti ile araç salımlarını önemli ölçülerde azaltmaktadır.
- Çeşitli uzman görüşlerine göre sürücüsüz araçların hızlanma ve yavaşlama etkinliklerinin optimizasyonu vasıtası ile yakıt tüketimi \%60'lara varan şiddetli azalmalar göstermektedir.

- Otonom araçlar (OA) birbirleri ve çevre ile etkileşime elverişli olduklarından dolayı kontrol edilmiş hız dâhilinde diziler halinde organize olabilirler. $\mathrm{Bu}$ da yakıt tüketiminde $\% 5$ ila \%20'lik bir azalmaya işaret etmektedir.

- Araçtan araca iletişimi kullanan ileri seyrüsefer (navigasyon) sisteminden dolay1 da yakıt tüketimindeki ciddi azalmalar özelikle de kalabalık kentsel trafik başta olmak üzere trafik tıkanıklık zonlarının önlenmesi yolu ile temin edilmektedir [3].

Tam otomat sürüşün başarılması adına takipte; çeşitli teknik konular çözülmelidir ve otomobil endüstrisi de bu işe odaklanacak gibi görünmektedir. Bütün devrim niteliğindeki yeniliklerde olduğu gibi sürücüsüz araçlardaki teknik gelişmeler tanzim edici (düzenleyici) işlemlerden daha ileri boyutlarda seyretmektedir. Dünya genelinde ise de karayolu trafiğinin bütün aşamaları ile ilgili düzenlemeler ana amaç en iyi karayolu güvenliği olacak bir şekilde yapılmaktadır böylelikle de otonom araçlar (OA) en azından öncülleri kadar ya da daha fazla güvenli olduklarını ispatlamak durumundadırlar. Sonuç olaraktan yasal zorunluluklar; kamu politikaları, trafik kodu, teknik standartlar ve haksız fiil hukuku dâhil olmak üzere en kritik konular arasında yer almaktadır. Örneğin telli direksiyon teknolojileri uzun bir süredir elverişlidir ve fakat araçlara entegre edilememiştir çünkü 1968 yılında Viyana'da imzalanan karayolu güvenliği toplantısı ortaya koymuştur ki aracın güzergahını belirlemek adına direksiyon sistemi dönen tekerlek ve diğer tekerlekler arasında mekanik bir sinırlılı̆̆ içermektedir.

\section{Materyal ve Yöntem}

Bütün kendinden sürüşlü araçların uç (ekstrem) ve acil durumlarda en doğru kararı verip vermediği noktası önemlidir. Bir yaya geçişine yakın bir noktada trafik ışığının araçlar için yeşil 
olduğu bir çerçeve tasavvur edildiğinde bir yayanın aniden yola atladığı durum göz önüne alınabilir. Belirlenen karayolu geçiş yerinin ekstrem bir ihtiyat dahilinde yakınlıkta olması ve aracın hızının da yaya geçişinden önce durmaya elverişli olmak adına yeterince az olması bir kural olmasına karşın eğer gerekir ise yayalar eğer ki bir risk olmadığına inanırlarsa yoldan geçebilirler. İşte bu noktada doğru kararın ne olacağı noktası oldukça önemli olmaktadır.

Şüphe yok ki sürücüsüz araçlara ilgi artmaktadır. 2015 y1lında bu bağlamda Boston Danışma Kurulu tarafindan icra edilen bir saha çalışmasına göre potansiyel araç müşterilerinin \%55'i bir yar1 otonom arac1 (OA) satın alabileceğini söyler iken bir diğer taraftan ise de \%44'ü tam otonom bir aracı satın alabileceklerini belirtmişlerdir. Bu kapsamda bütün ana otomobil üreticileri bu söz konusu talebi karşılamak üzere çalışmaktadır. Uluslararası bir pazar araştırma şirketi olan HIS verilerine göre ise 2020 yılında 4 ve 5. düzeyden otonom araçların (OA) pazar pay1 \%0,004 (4200 araç) olacak olup bu oran 2025 y1lı itibari ile ise \%0,5'e (578.000 araç) yükselecek iken 2030 y1lı itibariyle ise de $\% 3,8$ 'e ulaşacaktır (4.503.000 araç) [4].

\section{Otonom Teknolojileri}

Otonom teknolojileri günden güne daha sofistike bir hale gelmektedir ve de teknik erişilebilirliği artmaktadır, bazı durumlarda ise de ticari araçlarda halihazırda kurulmuş vaziyettedir. Muhtelif araç üreticileri 2017 y1lı itibari ile yüksek otomat araçları üreteceklerini duyurduklarından dolayı da otonom araçların (OA) yakın bir gelecekte gelişmiş ülkelerde görünürlüğünü arttıracağ1 hususu gerçekçi görünmektedir. 2030 yılı itibari ile çok ciddi sayıda sürücüsüz aracın yollarda seyrüsefere başlayacağı tahmini yürütülebilirdir.

$\mathrm{Bu}$ kapsamdaki çalışmalarda bir otonom aracın (OA) ne olduğuna ve otonom kilavuzluk seyrüsefer ve kontrol (AGNC_OKSK) algoritmasının kabaca bir testi için planlanan aracin bir simülasyon modelinin gerçekleştirilmesine odaklanılmaktadır. MATLAB ve SIMULINK; bu söz konusu modelin gelişimi için bir platform olarak kullanılmaktadır. Model, otonom kılavuzluk seyrüsefer ve kontrol (AGNC_OKSK) algoritması tarafindan kumanda edildiğinden dolayı dönme açısına dayalı olaraktan aracın bir sonraki konumu ve doğrultusunu hesaplamak adına geliştirilmektedir. $\mathrm{Bu}$ da yenilenmiş bir radyo kontrol araç şasesini kullanan otonom aracın (OA) küçültülmüş bir modelinin tasarımına öncülük etmektedir. Otonom araç (OA) ardından engel önleme dahilinde bunu önceden belirlenen bir coğrafik konuma seyrüsefer etmek adına kızıl ötesi sensörler ya da ultrason ve bir küresel konumlanma sistemi (GPS_KKS) ile donatılmaktadır.

Otonom araçlar (OA) ya da otomat kılavuzlu araçlar (OKA_AGV) bir sürücüsüz hareketli robot olup muhtelif orta mesafeli (hava ya da su) uzaktan kumanda vasitası ile ya da bir yüzey boyunca (karasal otomat kılavuzlu araç) kontrol ve seyrüsefer edilebilmektedir. Otonom araçlar (OA) yakın bir dönemde robotiğin bir alt kümesi olarak geliştirilmiştir ve üç temel şekilde teşekkül etmektedir. Bunlar ise hava, kara ve denizaltıdır. Otonom araçlar (OA); insansız hava araçları (IHA), sualtı keşif ve endüstriyel taşıma gibi birçok uygulamada yaygın olarak kullanılmak adına geliştirilmektedir. Otonom araçların (OA) muhtemel uygulamaları; diğer gezegenlerin yüzeyinin keşfi için ve örneğin yeraltı suyu boru hatlarının hat entegrasyonunun incelenmesi, radyoaktif alanlar ya da kimyasal yangınlar gibi insan hayatı için oldukça tehlikeli olan alanların incelenmesi bağlamında hassas bir şekilde teşekkül eden uçuşu ihtiva etmektedir. İnsansız hava araçları (İHA) otonom araçların (OA) genel sinifi olup temelde askeri kuvvetlerin keşif amacı ile kullanılmaktadır. Karasal otomat kılavuzlu araçlar (OKA_AGV) söz konusu bu araçların çoğu örneği bomba imhada olduğu gibi günümüzde askeriye için kullanılıyor olmasına karşın halen geliştirilme aşamasındadır, hâlihazırdaki mahiyet dâhilinde da otomat kılavuzlu araçların (OKA_AGV) mevcut 
durumdaki ulaştırma araçlarının çoğu ile yer değiştirmesi kuvvetle muhtemeldir. Bir otonom aracin (OA) birincil görevi aracin karşılaşabileceği herhangi bir engeli önlediğinde önceden programlı bir güzergâhı seyrüsefer etmektir. Münhasır yerde ve mücavir alanında ne olduğunu görmek adına sensörlerin kullanılması sureti ile araçlar bu görevi başarabilirler [5].

\section{Temel Araç Nitelikleri}

Otonom araç (OA) aracın karşılaması muhtemel engelleri önlerken bir ön programlı güzergâhı seyrüsefer etme ihtiyacı hissetmektedir.

- Araç: Boyutlandırılmış model araç

- Araç tekerleği: 4 teker

- Sürüş gücü: arka teker

- Dönme: ön teker

- Güç tipi: bateri gücü

- Minimum hiz: $3 \mathrm{~km} / \mathrm{saat}$

- Maksimum hiz: $6 \mathrm{~km} / \mathrm{saat}$

- Dönme açısı: hem sağ hem sol için $30^{\circ}$

- Temiz, açık gökyüzü: araç sadece dışarıda kullanılmalıdır.

- Seyrek dağınık engeller dâhilinde sert yüzeyde hemzemin olarak kullanılır.

- Engeli aşmak için dur ve dön etkinlikleri ile 50 santimetre mesafede engel algilamaktadir.

Matematiksel modeller bir sistemin nihai tamamlanmış modelinin önemli bir unsurunu teşkil etmekte olup esasen mahiyet, fiziksel, matematiksel, görsel ve muhtemelen istatistiksel alt modellerin bir toplamidir. Hemen hemen bütün matematiksel modeller kisitların çıkartılması yolu ile üretildiğinden ve de modellenmesi gereken sistem hakkındaki kullanışı hâlihazırdaki hiçbir model bu söz konusu problemde doğrudan kullanılabilmek üzere uygun bulunmamaktadır.

Araç hareketini karakterize eden matematiksel denklemler, Newton'un 2. hareket yasasının uygulanması sureti ile uygulanmaktadır ve de kısıtlar da ilgili bağıntılardaki kabuller tarafından empoze edilmektedir. Gövde hareketi ile ilgili üretilen denklemlerin kullanılması dâhilinde SIMULINK modeli geliştirilmektedir. Destekleyici MATLAB tip 2 fonksiyonları ise SIMULINK'teki blok diyagramlarındaki magenta (mora çalan kırmızı) rengi ile gösterilen özel bloklar için üretilmektedir [6].

Simülasyonlar amaç başına olacak şekilde model doğrulamanın sınırlı test amaçları dâhilinde yürütülmektedir. İtme kuvvetinin değişen değerleri ile dönme açısının söz konusu bu muhtelif terkipleri için kullanılmaktadır. Grafiklerden gözlemlenebileceği üzere itme kuvveti artarken nihai hız da artmaktadır, eş anlı olarak toplam döngüsel güzergâh da tamamlanmaktadır. Aynı itme kuvveti altında dönme açısı büyüdükçe dönme sayıları da artmaktadir.

Grafikler açık bir şekilde göstermektedir ki model yeterli ölçüde çalışmaktadır ve girdi başına çıktı üretilmektedir. İlk grafikte araç düz bir çizgide ilerler iken bu dönem açısının sıfıra eşit olan değeri dâhilinde gerçekleşmektedir. İkinci grafik göstermektedir ki araç dönme açısının sinusoidal dalgaya göre değişmesinden dolayı sinusoidal bir güzergâhta hareket etmektedir.

\section{Uygulama ve Başarımlar}

Problem başlangıçta nispeten kolay görünmesine karşın bir dizi saklı zorluk bulunmaktadır. Literatür araştırmasının yürütülmesi sureti ile de gözlemlenebilmektedir ki çalışma, yürütülen akademik çalışmaların yanı sıra profesyonel versiyonları için de çok boyutlu bir ilerleme sergilemektedir. Sualtı senaryosundaki otonom araç (OA) uygulamaları ise hava uygulamalarının yanı sıra kara uygulamalarında da muhtelif kurumlar tarafından çalışılmaktadır. $\mathrm{Bu}$ tarz çalışmalar kapsamındaki hedef bilahare bir karasal otonom aracın (OA) küçültülmüş bir modelinin gerçekleştirilmiş bir halinin güncel olarak kullanışlılığının ortaya konulmasıdır.

Karasal araç için basitleştirilmiş bir model geliştirilmiştir. Model; dönme açısı olan ve 
başarılı bir şekilde çalışan girdi değişkenlerinin muhtelif değerleri ile test edilmektedir. Model; kılavuz ve kontrol algoritması tarafindan üretilen komutların doğruluğunun niteliksel olarak sağlanması için kullanılabilmektedir. Daha ileri gelişmeler ise aynı zamanda da daha gerçekçi bir yol ile başarmak adına yapılabilmektedir ve ardından da kontrol algoritmasının nitelik testi için kullanılabilmektedir.

Carl Benz 1886 yılında otomobili keşfettiğinden beri birçok önemli araç mahiyeti geliştirilmiştir. Bunlardan bazıları taşımacılık tasarımı ve gövde altına şasi ve tekerleklerin entegrasyonunun terki gibi daha önceki mahiyetlerin kalkması ve mantıksal olarak sürekli gelişimi ile ilgili olabilmektedir [7]. Araç mahiyetini etkileyen ana unsur aracın kullanım amacidır. Bu durum özellikle de ticari araçlar dikkate alındığında görülmektedir. Bunun ile de beraber geniş bir çeşitlilikteki yolcu araçları üstü açılır arabalardan geliştirilmiştir ve de istasyon vagonları ve minivanların (hafif ticari) yanı sira ara sahibinin yaşam tarzına göre sedan ve kısa kasa araçlarla kullanım amacına göre arazi araçları da niteliklendirilmiştir. Kullanım tipi dahi; küçük teslimat kamyonetleri, minibüsler ve diğer pazarlarda hafif kamyon olarak bilinenler için oldukça önemlidir. Yakından bakılacak olur ise arka tekerlek çekişli boyuna yerleştirilmiş motorların hâkimiyetinden sonra son on yıllar içerisinde ön tekerlek çekişli enine kurulu ön motorlara doğru bir kayış söz konusu olmuştur. Dahası hâlihazırda güç trenlerinde elektrifikasyona doğru bir eğilimi söz konusu olup bu da $\mathrm{CO}_{2}$ şartnameleri, daha az gürültü salımları ve diğer avantajları dayalı olaraktan daha fazla sürdürülebilirlik dâhilinde değerlendirilmektedir. Bütün bu değişimlere karşın, mahiyetlerin söz konusu bu çeşitliliğinin desteklenmesi adına muhtelif pazar kesimleri tarafından sürdürüleceği bağlamındaki amaçların optimizasyonu üzerindeki uyuşmazlıklardan dolayı hâlihazırdaki sürüş mahiyetinin ortadan kalkması beklenmemektedir. Örneğin Amerika Birleşik Devletleri'nde kırsal bir alan, Çin'in büyük bir kentine nazaran nerede ise bütünü ile farklı sürüş gereksinimlerine sahip olmaktadır.

Pazarda bulunan araç modellerinin çeşitliliği ise motor şovlarda gösterilen araçların mahiyet çeşitliliği ile paralellik göstermektedir. Destek (asistan) sistemleri ve kısmi otomasyon tanıdık araçlar için çok az durumlarda mahiyet değişimini ifade etmektedir. Araçlardaki daha zayıf diş görüntünün olduğu geçmiş yıllar boyunca görsel eğilimi, gövde rijitliği ile ilgili gereksinimler ya da tarz gereksinimine göre tanzim edilmektedir, bunun ile de beraber ultrason otopark yardımları, arka görüntü kameraları ya da mücavir alan görüntüleri gibi telafi edici sistemlerin kullanımını desteklemektedir. Bunun ile de beraber sürücü destek sitemleri genelde çok azı bir araç model dizisi için standart donanımı içermekte olduğundan dolayı mahiyeti değiştirmemektedir. Sonuç olarak araç üreticileri araç tasarımı adına gerekli olmaktadır bu neden ile de donanımı olmayan sürücüler tarafından güvenli bir şekilde sürülebilmektedir.

Aşağıdaki alanlar arasında bir ayrım yapılmaktadır:

- Araç gövdesi

- Sürüş

- Şasi

- Dâhili donanım

- İnsan makine ara yüzü (HMI_İMA)

İki kullanım durum olan 'eyaletler arası pilot' ve 'tam otomasyon' oldukça farklı yetkinliklere sahip iken bir diğer taraftan ise de otonom sürüşe gelindiğinde ise bir farklılık yoktur, araç mahiyetlerini değerlendirmeye gelindiğinde ise de her iki kullanım durumu da ileri düzey yetkinlik için elverişli bir sürücüye sahip olmak ile sınırlandırılmış bir durumdadır. Tam otomasyon kullanım durumu için otonom sürüş daha ileri bir düzeyde kullanılabilirdir ve devir teslim daha az talep edilmektedir. Bunun ile de beraber her iki durumda da araç kılavuzluğunun ileri elverişlilikteki bir sürücü gibi münhasır işlevde sürücü ehliyeti olan bir insan tarafından kısitlama olmaksizın muhtemel olmaktadır. 
Dolayı ile her iki durum için de araç kılavuzluğu otonom ya da manüel, karma bir tür gibi desteklenmektedir [8].

Sensörler otonom sürüş için otonom araçlar (OA) adına adeta her yeri inceleme açısını temin etmekte olup eğer günümüzde akıllı görüş hedefleniyor ise karmaşık paket çözümlerde net netice alınabilecektir. Eğer ki bir standart, esasen otonom sürüş adına bir yetkinlik için teşekkül ettirilmişse, bu geliştiriciler için faydalı olacaktır zira doğru bir alg1 üzerinde üstün sensör konumunu işgal etmek adına uygundur.

\section{Otomasyon ve Manüel Değerlendirmeleri}

Sürüş

Otonom olmayan benzeri araçlardan ziyade potansiyel olarak kalan manüel seyahat kesimleri için sürüş mahiyetinin farklı değerlendirmek adına hiçbir sebep yoktur. Bununla beraber otonom sürüş manüel sürüşe kıyasla, daha verimli bir sürüşü muhtemel kılmak adına trafik telematikleri ile etkileşimi kolaylaştırmaktadır. Sürüş özellikleri; zaman ve enerji gereksinimlerine bağlı olaraktan kontrol edilebilmektedir. İlkesel olarak söz konusu bu seçenekler hâlihazırda kısmi ya da yüksek otomat sürüş işlevleri dâhilinde araçlar üzerinde elverişli olmakta olup bu da otonom sürüşün bir sonraki adım boyunca sürüşü mahiyetinde çok az değişimi sonucunu ortaya çıkartmaktadır. Bu da bateri elektrikli sürüşler gibi indirgenmiş bir elverişlilik dâhilinde sürüş mahiyeti faydasını doğuran daha ziyade yeni bir ağ seçeneğidir.

Manüel sürüş standart gereksinimler dâhilindeki bir şasiyi gerektirir iken bir diğer taraftan ise de otonom sürüşün uzun aşamaları işgalcileri sürüş işleminden çıkarmaya imkân tanımaktadır. Otomasyon, ne araç hılanması nedeniyle işgalcileri etkileyen enine ne boyuna kuvvet ve ne de sürüş dinamikleri için elle tutulur bir hassasiyeti gerektirmektedir. $\mathrm{Bu}$; araç hareket sensörlerine dönebilir olup yörüngenin düzenlenmesi ve böylelikle de dinamik ve konforlu hale getirilmesi adına elektronik denge kontrolü için uzun zamandır kullanılmaktadır.
Otonom sürüş, sürüş süresine bağlı olaraktan araç mahiyetine göre daha az bir değişim göstermektedir. Hâlihazırdaki 1,5 kişilik değerindeki araç işgal istatistiği dâhilinde bu kişilerin çoğunluğu, okuma, çalışma ya da uyuma gibi günümüz yolcusu için elverişli olan seçeneklerin tercihini yapabilecek durumda değildir [9]. Otonom sürüş bunu mümkün hale getirmektedir. Buna ilave olaraktan da etkinlikler, 4 boyutlu sinemayı ifade eden mücavir alan sesi ve büyük bir ekran üzerinde çoklu ortam toplantısı gibi izin verilmeyen dikkat dağınıklıkları ile sonuçlanabilir. Kullanıcı grubuna daha ileri bir değişim söz konusu olmaktadır. Daha önceleri sürüş otoritesine sahip olan bir sürücü her zaman için gerekliydi. $\mathrm{Bu}$ kısıt artık tamamen aynı şekilde devam etmeyecek olup bu da hâlihazırda araçtaki yolculardan herhangi birisi olabilen yeni bir kullanıc1, otonom arac1 (OA) kullanabilir durumdadır. $\mathrm{Bu}$ kişi, otomobil kullanma izni olmayan bir engelli ya da yaşından dolayı otomobil kullanma izni olmayan bir genç ya da çocuk da olabilir. Buna bağlı olaraktan aynı zamanda araç ve işletimsel mahiyet de bu söz konusu yolcular için uyarlanmalıdır.

Eğer ki odak noktası bireysel araçlara kadar uzatılır ise sistem sınırları, çevre ve diğer karayolu kullanıcıları ile etkileşimi içermek adına bu kapsamda genişletilmektedir. Araçların bağlantılar arasılığ 1 erken dönemdeki bütün araçlar için teknoloji olarak teşekkül etmekte olup bu da otonom sürüşün trafiğe ilk girişinin temelde yeni hiçbir şey getirmeyeceği sonucunu çıkartmaktadır. Bunun ile de beraber araçların otomasyonu aynı zamanda muhtemel yeni kullanım şekilleri ortaya çıkartmak sureti ile münhasır performans yeterliliği artışları ortaya çıkartmaktadır. Otonom araçlarda (OA) öngörülen daha yüksek hassasiyet düzeyleri ise elektronik kontrollü manevraların hâlihazırdaki trafikte bu şekilde zar zor makul olabilen bir ihtimaliyete haiz olmaktadır. $\mathrm{Bu}$ firsatlar özellikle de dar sürüş şeritlerinde sürüş ya da araçlar arasındaki oldukça küçük mesafeler dâhilindeki bir konvoy sürüşünü de içermektedir. 
Birim zamanda trafik alanından geçiş yapan trafik unsuru sayısı artmaktadır [10].

\section{Sonuçlar ve Tartışma}

Seyahat talebi ve trafik hızının arttırılması sureti ile ve de toplu ulaştırmanın devre dışı bırakılması dâhilinde trafik tıkanıklığı, kentsel dağılma ile ilgili maliyetler ve hareket dengesizliğini de tetiklemektedir. Örneğin eğer ki otopark ücretli ve karayolu ise ücretsiz ise otonom araçlar (OA) otopark için ödemeyi engellemek, trafik tıkanıklığ1 ve benzeri problemlerin artışını önlemek adına caddelerde seyrüsefer yapabilirler. Bazıları otonom araçların (OA) toplu ulaştırmaya olan gereksinimi ortadan kaldırdığını savunmaktadır ve fakat yüksek kapasiteli toplu ulaştırma halen ana seyahat koridorlarında bir ihtiyaç olmaya devam edecektir ve otonom teknolojileri duraklar ve istasyonlara erişimin geliştirilmesi ve işletim maliyetlerinin azaltılması sureti ile toplu ulaştırmayı destekleyebilmektedir.

Şu politikalar faydaların maksimize edilmesine destek olabilirdir:

- Güvenlik ve verimlilik için yeni teknolojilerin test ve tanzim edilmesi

- Ahlaki ve toplumsal hedeflere dayalı olaraktan otonom araçların programlanması gereksinimi

- Çelişkileri, trafik tıkanıklığını ve riskleri minimize etmek adına karayolları ve kurb yerlerinin etkin bir şekilde tanzim edilmesi ve ücretlendirilmesi

- Devlet yollarında az yolculu araçlara karşın çok yolculu ve paylaşımlı araçların desteklenmesi

- Ana seyahat yollarında yüksek kapasiteli toplu ulaştırmanın desteklenmesi

- Paylaşımlı araçların avantajını elde etmek adına otopark gereksinimlerinin azalt1lması

- Kentsel dağılmanın etkinliğini azaltmak adına fiyat gelişiminin etkin bir şekilde uygulanmasi

- Caddelerin yenden tasarımı ve kentsel yaşanabilirliğin geliştirilmesi için araç trafik azaltmalarının kullanılması
Otonom araçların (OA) yakın zamanda ticari olarak elverişli olabileceğine dair yakın dönem duyuruları ümit vermektedir ki söz konusu bu teknolojiler çoğu ulaştırma problemini hızlıca çözebilmektedir. 2030 yılı itibari ile bu gibi araçların yeterince güvenilir bir hal alarak insan sürücülü araçların yerlerine ikame olmaya başlayacağı savunulmaktadır [11].

Özetle otonom sürüş dâhilinde kimse seyahat süresince sürüş ile sürekli sorumlu değildir. Muhtelif kullanımlar araç içyapısı üzerinde ve insan makine etkileşiminin tasarımı ile ilgili dikkate değer etkilere haizdir.

Çevre ile bağlantıdaki değişimler anlamına gelen sürüş görevinde sorumluluk almak ise mümkün olmaktadır. $\mathrm{Bu}$ görsel eşleştirme ve yolcu üzerindeki dinamik sürüş ve karayolu yüzeyinden kaynaklı kuvvet etkilerinin ayrıştırılması için algısal bir kanala uygulanmaktadır. $\mathrm{Bu}$ durum şasiler için başarılması çok zor bir husus değildir ve fakat yolcular için ise aciliyet arz eden bir duruma işaret etmektedir.

Otonom sürüş her zaman bir telli tahrik edici kontrol vasıtası ile yürütüldüğünden dolayı çok yüksek düzeydeki bir hareket kontrolü hassasiyeti kabulü yapılmaktadır. Bir taraftan bu özellikle de eğer ki insanlar tarafından döndürme hareketi daha fazla planlanmiyor ise sadece yuvarlanmaya karşı direnç için yeteri olmayan bir kullanım alanı dâhilinde muhtemeldir ki araçlardaki yuvarlanmaya karşı gereçler ile bağlantı durumu dâhilinde dahi yeni dönme mahiyetlerine imkân tanımaktadır. Diğer taraftan ise söz konusu bu hassasiyet araçtan araca kütle aktarımı gibi günümüzde halen pek de olağan görülmeyen mahiyetlere imkân tanımak adına ya da altyapıdan daha iyi faydalanmak adına aynı hassasiyet düzeyi ile diğer otonom araçlara (OA) bağlantı imkânını oluşturmaktadır [12].

Otomasyon, araç mahiyetinde devrim niteliğinde bir sıçrama değildir. Bazı mahiyetler otomasyona göre daha dezavantajlı olmasına karşın, dört tekerlekli yolcu aracı gibi klasik araç 
mahiyetlerinin, otomat karayolu trafiğine baskınlığının devam etmesi beklenmektedir. Bunun ile de beraber uygun alanlarda ortaya çıkan yeni firsatlar söz konusu olmakta olup sadece bu söz konusu mevkilerin cazibesi, genel münhasır motorlu taşıt için olan mahiyetin üstünlüğüne nazaran daha ziyade belirli düzenlemeler ve erişim kontrolü dâhilinde yürütülmektedir.

Günümüzde hâlihazırdaki durumda olduğu gibi otonom araçlar (OA) için mahiyetin belirlenmesi ve özellikle de araç dâhili tasarımının simüle edilmesi sureti ile seyahat süresi kazançları gündemde olacaktır. Otomat sürüş teknolojisi günümüzdeki pazar üzerinde oldukça muhtelif olumlu sonuçları ortaya çıkartacaktır.

Bir taraftan hareketli oturma odası, ofis ya da yatak odası gibi hizmet eden koltuklu sedanları (aile arabası) andıran pahalı ve yüksek konfor tabanlı araçlar söz konusu olacaktır. Diğer bir taraftan ise indirgenmiş maliyet faydasına haiz araçlar ulaştırma hizmetleri için gerekli ekipmana sahip olmak sureti ile kullanılacak olup ve fakat küçük şehir otobüslerini andırmaktadır ve ne caziptir ve özellikle ne de konforludur. Belirtilen kullanım durumları için geliştirilen teknoloji hizmet sektöründe önemli değişimler meydana getirecek olan çok sayıda yan ürün ve ikincil ürünün ortaya çıkması sonucunu doğuracaktır [13].

\section{Teşekkür}

Birlikte mesai yaptığımız hocalarımıza teşekkür ederiz.

\section{Kaynaklar}

[1] B. Schoettle, M. Sivak, (2014). A survey of public opinion about autonomous and selfdriving vehicles in the US, the UK, and Australia.

[2] D.J. Fagnant, K. Kockelman, (2015). Preparing a nation for autonomous vehicles: opportunities, barriers and policy recommendations, Transp. Res. Part A 77 (Supplement C)167-181, doi: 10.1016/j.tra.2015.04.003.

[3] I. Paromtchik, C. Laugier, (2015). Motion generation and control for parking an autonomous vehicle, ICRA 3112-3117.
[4] J. Cui, G. Sabaliauskaite, (2017). On the alignment of safety and security for autonomous vehicles, IARIA CYBER, Barcelona, Spain.

[5] J. Jansson, (2017). Decision Making for Collision Avoidance System, SAE, Detroit, Michigan, 2002, pp. 1-10. [2] www.redcross.org.lb (Accessed 15 March)

[6] L. Davis, (2017), Dynamic origin-to-destination routing of wirelessly connected, autonomous vehicles on a congested network, Phys. A 478 93-102.

[7] M. Ragul, V. Venkatesh, (2015). Autonomous vehicle transportation using wireless transmission, IJET 5 (2) 811-819.

[8] M. Zhu, H. Chen, (2017). A model predictive speed tracking control approach for autonomous ground vehicles, MSSP 87, Part B 138-152.

[9] National Center for Statistics and Analysis, (2005). National Highway Traffic Safety Administration, Traffic Safety Facts.

[10] National Highway Traffic Safety Administration, (2017). 2016 Fatal motor vehicle crashes: overview, National Center for Statistics and Analysis U.S. Department of Transportation, Washington, D.C. DOT HS 812456.

[11] R. Mishra, A. Singh, R. Kumar, (2016) Vanet security: Issues, challenges and solutions, in: International Conference on Electrical, Electronics, and Optimization Techniques (ICEEOT), IEEE, 2016, pp. 1050-1055, doi:10.1109/ICEEOT. 2016.7754846.

[12] S. E. Shladover, (2007) "Progressive deployment steps leading toward an automated highway system (AHS)," in Transportation Research Record No. 1727. Washington, DC: Transportation Research Board, 2000, pp. 154-161. [11] S. E. Shladover, "PATH at 20 - History and major milestones," IEEE Trans. Intell. Transp. Syst., vol. 8, no. 4, pp. $584-$ 592.Society of Automotive Engineers (SAE), (2016). SAE-J3016: Taxonomy and definitions for terms related to driving automation systems for on-Road motor vehicles. 